\title{
KEBUTUHAN LAYANAN KEAGAMAAN UMAT KHONGHUCU DI DKI JAKARTA
}

\author{
Anik Farida \\ Puslitbang Bimas Agama dan Layanan Keagamaan, Kementerian Agama RI \\ anik_farida@yahoo.co.id \\ dan \\ M. Taufik Hidayatulloh \\ Kantor Kementerian Agama Kab. Bogor, Jawa Barat \\ taufikmtht@yahoo.co.id \\ Artikel diterima 28 Desember 2017, diseleksi 23 Mei, dan disetujui 25 Juni 2018
}

\begin{abstract}
The objective of this research is: to describe forms of religious services that have been or have not been provided by the local government of Jakarta; to describe forms of religious services needed by Confucians in Jakarta; to discover social relations between Confucians and other religious adherers, communities, and the state in Jakarta. The research was conducted in Jakarta in 2017. The subject of the research includes eight interviewees who come from board members of Majelis Tinggi Agama Khonghucu Indonesia Pusat (MATAKIN/ Central Board of High Council of Confucianism in Indonesia), Majelis Tinggi Agama Khonghucu Indonesia DKI Jakarta (MAKIN/Jakarta Board of High Council of Confucianism in Indonesia), Ministry of Religious Affairs in Jakarta (Section of Harmony of Religious Communities), Forum Kerukunan Umat Beragama (FKUB/Jakarta Board of the Forum of the Harmony of Religious Communities), religious elites or board members of MAKIN; all of them were elected purposively. The techniques of data gathering includes deep interview with informants and document analysis. The data is analysed by using the techniques offered by Miles and Huberman, which is data reduction, data presentation, and conclusion. The result of the research indicates that: (1) comparing educational and residence services, many issues have been found in educational services; (2) in the legal field, Confucians need restitutions of legal status to the socialisation of implementation techniques; in the religious field, they need the return of the managing of religious places (Kelenteng) to them, as well as their religious teaching and symbols; they also need other services in the fields of civil rights, supervision of religious communities, education, and management; (3) this research did not find the presence of physical conflict. However, it has discovered hidden conflicts related to the function of Kelenteng, education, and religious convertion.
\end{abstract}

Keywords: Confucian Community, MATAKIN, Religious Service, Social Relations.

\begin{abstract}
Abstrak
Tujuan yang ingin dicapai dalam penelitian ini adalah mendeskripsikan bentuk layanan keagamaan yang sudah dan belum diberikan oleh pemerintah di DKI Jakarta; mendeskripsikan bentuk layanan keagamaan yang dibutuhkan oleh umat Khonghucu di DKI Jakarta; mengetahui hubungan sosial umat Khonghucu dengan umat lainnya, masyarakat dan negara di DKI Jakarta. Penelitian ini dilaksanakan di DKI Jakarta pada Tahun 2017. Subjek penelitian sejumlah 8 orang merupakan unsur pengurus Majelis Tinggi Agama Khonghucu Indonesia Pusat (MATAKIN), pengurus Majelis Tinggi Agama Khonghucu Indonesia DKI Jakarta (MAKIN), Kantor Wilayah Kementerian Agama DKI Jakarta (Bidang Kerukunan umat Beragama), Forum Kerukunan umat Beragama DKI Jakarta, Tokoh agama maupun pengurus Majelis Agama Khonghucu Daerah Kota (MAKIN) yang dipilih secara purposive. Teknik pengumpulan data yang digunakan adalah wawancara mendalam dengan berbagai informan dan penelusuran dokumen. Data dianalisis dengan menggunakan teknik yang dikemukakan oleh Miles dan Huberman, yakni reduksi data (pemilahan), penyajian data dan penarikan kesimpulan. Hasil penelitian menunjukkan bahwa: (1) Di antara layanan pendidikan dan layanan kependudukan, layanan pendidikan inilah yang paling banyak ditemukan masalah; (2) Layanan yang dibutuhkan umat Khonghucu di bidang status hukum berupa pemulihan status hukum sampai kepada sosialisasi aturan pelaksanaan, di bidang keagamaan mulai dari pengembalian rumah ibadah Kelenteng ke pengelolaan umat Khonghucu sampai kepada pengembalian ajaran dan simbol keagamaan, di bidang layanan hak sipil, di bidang pembinaan umat, di bidang pendidikan, dan di bidang keorganisasian. (3) Penelitian ini tidak menemukan adanya konflik atau gesekan yang bersifat fisik, namun terjadi konflik terselubung terkait fungsi Kelenteng, bidang pendidikan dan konversi agama.
\end{abstract}

Kata Kunci: Umat Khonghucu, MATAKIN, Layanan Keagamaan, Hubungan Sosial.

Jurnal Multikultural \& Multireligius Vol. 17

No. 1 


\section{PENDAHULUAN}

\section{Latar Belakang Masalah}

Keberadaan agama Khonghucu sudah ada sebelum zaman kemerdekaan. Hal tersebut ditandai dengan keberadaan Kelenteng Thian Ho Kiong di Makassar tahun 1688, sejenis organisasi MATAKIN Tahun 1729 di Batavia (Ing, Tjhie Tjay, 2013 : 2). Seiring zaman, istilah penyebutan organisasi tersebut lebih diIndonesiakan menjadi Tionghoa Hokian pada tanggal 17 Maret 1970. Pada zaman Orde Lama (tepatnya tahun 1955), secara resmi berdiri Majelis Tinggi Agama Khonghucu Indonesia (disingkat MATAKIN). Era Orde Lama ini menandai kemesraan bentuk hubungan pemerintah dan masyarakat Tionghoa secara umum. Keberadaan agama Khonghucu semakin diakui manakala termuat dalam UU No. 1/PNPS/1965 tentang Pencegahan penyalahgunaan dan/atau Penodaan Agama. Dalam Pasal 1 disebutkan bahwa agama-agama yang dipeluk oleh penduduk Indonesia ialah Islam, Kristen, Katolik, Hindu, Buddha dan Khonghucu.

Namun pada zaman Orde Baru, kebijakan politik pemerintah Indonesia terpengaruh iklim geopolitik saat itu yang renggang dengan $R R C$, menjadikan hubungan negara dengan umat Khonghucu ikut renggang. Menyusul dikeluarkannya Keputusan Presiden No. 6 Tahun 2000 tentang pencabutan Inpres No. 14 tahun 1967 tentang larangan terhadap agama Kepercayan dan Adat istiadat, serta hal-hal yang berbau Cina secara terbuka di muka umum.

Pasca Orde Baru, agama Khonghucu mulai dikenal sebagian masyarakat Indonesia dan hal-hal yang berhubungan dengannya mulai dihidupkan kembali. Agama Khonghucu semakin mendapatkan tempat dan memiliki hak yang sama dengan agama-agama lain di Indonesia.
Dengan keberadaan umat Khonghucu secara administrasi negara, sehingga negarapun berkewajiban memenuhi kebutuhan umat Khonghucu secara administratif berdasarkan agamanya. Dalam rangka memberikan layanankeagamaanbagiumatKhonghucu, pemerintah melalui Kementerian Agama telah melakukan upaya struktural dengan membentuk struktur organisasi setingkat kepala Bidang Bimas Agama Khonghucu dalam Struktur Pusat Kerukunan umat Beragama (PKUB) pada tahun 2010. Terakhir penyempurnaan tata organisasi di Kementerian Agama dalam rangka melakukan pembinaan terhadap umat Khonghucu dengan membentuk nomenklatur baru dengan nama Pusat Bimbingan dan Pendidikan Khonghucu di tahun 2017.

Banyak regulasi yang sudah dikeluarkan Kementerian Agama, mulai dari bidang pendidikan melalui PP No. 5 tahun 2007 tentang Pendidikan Agama dan Pendidikan Keagamaan bagi umat Khonghucu dan memasukan pendidikan agama Khonghucu dalam kurikulum nasional. Regulasi bidang perkawinan melalui Instruksi Menteri Agama No. 1 tahun 2006 tentang sosialisasi Status Perkawinan, Pendidikan dan Pelayan terhadap penganut agama Khonghucu.

Teristimewa layanan administrasi umum tentang kependudukan sudah diaturmelaluiSuratMendagriNo.470/336/ SJ, tertanggal 24 Februari 2006, perihal layanan Administrasi kependudukan penganut agama Khonghucu. Menjadikan umat Khonghucu dapat dilayani sebagai umat beragama di Indonesia.

Setelah hampir 11 tahun dari diakuinya Khonghucu secara administratif sebagai sebuah agama di Indonesia, keberadaan agama Khonghucu semakin eksis di masyarakat. Namun muncul problematika internal umat Khonghucu, di mana umat Khonghucu sendiri tetap ingin bertahan pada agama 
yang selama ini mereka sudah bernaung di dalamnya dan tidak menginginkan untuk secara administrasi (KTP) mereka diubah menjadi agama Khonghucu yang disebabkan mereka masih trauma dengan perlakuan pada zaman Orde Baru. Dengan keadaan seperti ini membuat problematika sendiri dalam pendataan umat Khonghucu secara administratif. Hal ini menghambat proses pendataan di internal umat Khonghucu. Belum lagi masalah interaksi sosial umat Khonghucu dengan berbagai pihak yang selama ini terkesan menunjukkan sikap eksklusifitas. Hal ini telah mengundang tanda tanya, apakah interaksi sosial ini mengalami persoalan atau tidak di masyarakat, dengan pemerintah dan umat agama lainnya, terutama pasca perpisahan umat Khonghucu dari agama Buddha.

Dari deskripsi di atas, kiranya unit kerja di bawah Kemenag membutuhkan masukan (input) berbasis riset tentang layanan keagamaan berbasis kebutuhan umat Khonghucu dalam rangka menetapkan kebijakan dan merumuskan berbagai program kegiatan layanan keagamaan. Untuk itu riset berjudul "Kebutuhan Layanan Keagamaan umat Khonghucu di DKI Jakarta” dilaksanakan.

\section{Masalah, Tujuan dan Kegunaan Penelitian}

\section{Masalah Penelitian}

Berdasarkan latar belakang di atas, maka permasalahan yang dikaji dalam penelitian ini adalah sebagai berikut: Bagaimana bentuk layanan keagamaan yang sudah dan belum diberikan oleh pemerintah di DKI Jakarta? Seperti apakah bentuk layanan keagamaan yang dibutuhkan Umat Khonghucu di DKI Jakarta? Bagaimana hubungan sosial Umat Khonghucu dengan umat lainnya, masyarakat dan negara di DKI Jakarta?

\section{Tujuan Penelitian}

Secara umum tujuan penelitian ini adalah memetakan model layanan terbaik bagi umat Khonghucu. Namun secara khusus, tujuan yang ingin dicapai dalam penelitian ini, yaitu untuk ; mendeskripsikan bentuk layanan keagamaan yang sudah dan belum diberikan oleh pemerintah di DKI Jakarta, mendeskripsikan bentuk layanan keagamaan yang dibutuhkan oleh umat Khonghucu di DKI Jakarta dan untuk mengetahui hubungan sosial umat Khonghucu dengan umat lainnya, masyarakat dan negara di DKI Jakarta.

\section{Kegunaan Penelitian}

Penelitian ini diharapkan dapat digunakan oleh Kementerian Agama RI, khususnya Pusat Bimbingan dan Pendidikan Khonghucu sebagai bahan dalam menyusun kebijakan yang terkait dengan pembinaan agama Khonghucu di Indonesia.

\section{Kajian Kepustakaan}

\section{Pengertian Agama dan Khonghucu}

Agama merupakan kontrol terhadap manusia dengan cara menciptakan aturan-aturan (regulare) yang pada akhirnya akan menciptakan keteraturan mutual, perekatan hubungan sosial (Turner, Bryan S, 2006 : 85). Salah satu sendi sosial masyarakat adalah agama. Agama, yang menyangkut kepercayaan serta berbagai prakteknya, benar-benar merupakan masalah sosial. Dalam masyarakat yang sudah mapan, agama merupakan salah satu struktur institusional penting yang melengkapi keseluruhan sistem sosial (Turner, Bryan S, 2006 : 85). Agama, telah dicirikan sebagai pemersatu aspirasi manusia, sebagai sejumlah besar moralitas, sumber

\begin{tabular}{l|l} 
Jurnal Multikultural \& Multireligius Vol. 17 & No. 1
\end{tabular} 
tatanan masyarakat dan perdamaian batin individu.

Khonghucu atau Konfusianisme adalahnama seorangfilsuf.Konfusianisme muncul dalam bentuk agama di beberapa negara seperti Korea, Jepang, Taiwan, Hong Kong dan Tiongkok. Dalam bahasa Tionghoa, agama Khonghucu seringkali disebut sebagai Kongjiao atau Rujiao. Di Indonesia, agama Khonghucu adalah istilah yang muncul sebagai akibat dari keadaan politik saat itu.

\section{Kebutuhan Umat}

Beberapa definisi kebutuhan dikemukakan berbagai ahli. Kebutuhan merupakan apa yang harus orang capai dan jika hal ini dihindari akan mengakibatkan terganggunya pengejaran tujuan yang sedang diupayakan oleh individu (Doyal dan Gough, 1991). Kebutuhan berhubungan dengan tujuan yang ingin dicapai oleh manusia. Selain itu, dalam sudut pandang lain disebutkan bahwa kebutuhan adalah suatu konstruk yang mewakili suatu daya dalam diri seorang individu, kekuatan sedemikian rupa untuk mengubah situasi yang ada dan yang tidak memuaskan ke arah tertentu (Murray diacu dalam Miller, 2005). Kebutuhan ini dapat mengarahkan dorongan (drivers) bagi seorang atau sekelompok orang untuk melakukan sesuatu yang dapat memuaskan ke arah tertentu.

Menurut Kamus Besar Bahasa Indonesia, pengertian umat adalah ; 1) para penganut (pemeluk, pengikut) suatu agama, penganut nabi, 2) makhluk manusia, manusia sekalian (bangsa) manusia. Dari pengertian ini dapat dirumuskan bahwa umat Khonghucu di Indonesia adalah orang-orang atau para penganut/pemeluk/pengikut dari sebuah agama yang bernama agama Khonghucu yang berdomisili di negara Indonesia dan sudah menjadi warganegara Indonesia serta tertulis di KTPnya beragama Khonghucu yang bernaung di bawah Majelis Tinggi Agama Khonghucu Pusat (MATAKIN) di tingkat pusat atau Majelis Agama Khonghucu Daerah (MAKIN) di tingkat Kota/Kabupaten.

\section{Hubungan Sosial}

Sebagai makhluk sosial, manusia melakukan berbagai aktivitasnya. Untuk terjadinya aktivitas tersebut memerlukan persyaratan tertentu berupa adanya interaksi sosial (Soekanto, Soejono, 2009 : 55). Melalui interaksi tersebut, maka abstraksi maksud dari manusia dapat ditransmisikan ke semua stakeholdersnya untuk diwujudkan ke dalam suatu aktivitas tertentu. Bahkan, interaksi manusia tidak saja dengan sesama manusia, melainkan juga dengan lingkungannya. Dasar-dasar interaksi antar manusia itulah kemudian dengan berbagai dimensinya telah melahirkan relasi kodrat sosial (Abidin, Zaenal dan Safe'i, Agus Ahmad. 2002 : 107).

Pengertian hubungan sosial dapat kita ketahui dari pendapat para ahli. Hubungan Sosial Menurut Bardis adalah suatu hubungan yang memungkinkan melibatkan dua atau lebih perorangan, kelompok atau sistem sosial yang saling mempengaruhi satu sama lain (Bardis, Panos D, 1979 : 148). Selanjutnya Turner mendefinisikan lebih spesifik bahwa hubungan sosial adalah sebuah situasi di manaperilaku seseorang secara sadar dilakukan kembali oleh dan mempengaruhi perilaku orang lain dan sebaliknya (Turner, Jonathan H, 1988 : 13-14). Dari pendapat para ahli tersebut dapat disimpulkan bahwa hubungan sosial merupakan hubungan antar individu, kelompok satu sama lainnya yang menghasilkan hubungan tetap dan dapat membentuk struktur sosial dan hubungan keterkaitan sosial satu sama lainnya. 
Berdasarkan kajian tersebut, hubungan sosial yang dimaksud dalam penelitian ini adalah hubungan yang dibangun umat Khonghucu dengan pemerintah, masyarakat dan agama lainnya. Baik dalam bidang sosial, maupun di bidang lainnya. Hal ini dapat mengungkap apakah umat Khonghucu telah melakukan sosialisasi diri secara terbuka atau masih bersifat esklusif pasca diterimanya Khonghucu sebagai sebuah Agama di tengah-tengah masyarakat, pemerintah dan agama lainnya.

\section{Penelitian Terdahulu}

Penelitian mengenai agama Khonghucu sesungguhnya sudah banyak sekali dilakukan oleh yang lainnya, termasuk Puslitbang Bimas Agama dan Layanan Keagamaan sudah melakukan beberapa kali penelitian. Hasil penelitan Sulaiman dari Balai Agama Semarang tentang Agama Khonghucu : Sejarah, Ajaran, dan Keorganisasiannya di Pontianak Kalimantan Barat menyebutkan antara lain Khonghucu ini bermula dari kepercayaan tradional yang bernama $R u$ Jiao, yang disempurnakan oleh Nabi Khongzi. Kedatangan agama Khonghucu di daerah ini tidak diketahui secara pasti, akan tetapi banyak tokoh agama yang mengaitkannya dengan datangnya etnis Tionghoa ke Kalimantan Barat abad ke 17. Pola kehidupan keagamaan penganut agama Khonghucu di Pontianak lebih bersifat tradisional karena lebih menonjolkan tradisi-tradisi yang diwariskan oleh leluhurnya. Karena itu, di Pontianak sudah ada bangunan tua sebagai tempat pemujaan umat Khonghucu, yang dikenal dengan pekhong atau kelenteng (Sulaiman, 2009).

Joko Tri Haryanto melakukan penelitian yang berjudul : Pembinaan Keagamaan Rohaniawan Khonghucu di Tuban Jawa Timur. Hasil penelitiannya menyimpulkan bahwa pola pembinaan umat Khonghucu oleh tokoh agama Khonghucu meliputi aspek-aspek kepercayaan, ritual dan sosial. Ketiga dimensi atau aspek tersebut membentuk suatu sistem keagamaan yang utuh, oleh karena itu pembinaan tokoh agama Khonghucu dalam pembinaan kehidupan beragama dalam masyarakat Tionghoa pada dasarnya tidak dapat dibagi-bagi secara parsial. Ketiga dimensi ini saling terkait dan berhubungan. Pola pembinaan dalam bidang kepercayaan pada umumnya dilakukan secara konvensional dalam khutbah kebaktian. Sedangkan kajian dan diskusi masih terbatas dengan kelompok umat tertentu. Pola yang dilakukan oleh rohaniawan dalam bidang sosial adalah memberi anjuran dan pendekatan secara pribadi terhadap umat Khonghucu untuk turut aktif dalam kegiatan-kegiatan sosial tersebut. Selain itu juga rohaniawan menyadari posisi dirinya sebagai tokoh sentral dalam bidang keagamaan juga mendorong diri mereka sendiri untuk bertindak sebagai contoh dalam segala bidang baik ritual maupun sosial (Haryanto, Joko Tri, 2010).

\section{METODE}

Tulisan ini hasil dari penelitian eksploratif, karena data yang akan digali secara naturalistik atau alamiah dapat dieksplorasi dari para tokoh kelompok agama, umat Khonghucu, lingkungan yang diteliti, maupun informan lainnya. Dengan demikian peneliti menggali informasi sedalam-dalamnya, karena belum banyak informasi yang dimiliki tentang pemetaaan kebutuhan umat Khonghucu.

Pengumpulan data dilakukan melalui tiga cara yaitu: (a) kajian pustaka dengan mempelajari beberapa dokumen, literaratur, tesis dan disertasi tentang Agama atau umat Khonghucu, (b) wawancara mendalam dengan pimpinan organisasi MATAKIN/MAKIN, Kemenag 
Kota DKI Jakarta, pengurus Kelenteng dan Lithang, tokoh agama atau rohaniawan, Penyuluh Agama Khonghucu dan umat Khonghucu, (c) observasi lapangan.

Penelitian ini memetakan kondisi umat Khonghucu di Indonesia, meliputi: umat Khonghucu yang eksis di wilayah tersebut, sistem pengorganisasian, jumlah umatnya, cara mempertahankan eksistensinya, budaya, hak-hak sipil mereka, serta hubungan sosial dengan masyarakat atau dengan pemerintah setempat.

Hasil penggalian data itu kemudian di-crosscheck sehingga diperoleh seperangkat pengetahuan tentang peta kebutuhan umat Khonghucu melalui pandangan umat Khonghucu dan tokoh Agama di wilayah penelitian. Data tersebut kemudian dianalisis secara deskriptif dan diklasifikasi sebelum diinterpretasikan.

Subjek dalam penelitian ini adalah para narasumber yang terdiri dari unsur umat, rohaniawan, akademisi, cendikiawan, guru agama dan penyuluh agama Khonghucu yang ada di bawah pengampuan Majelis Tinggi Agama Khonghucu Indonesia (MATAKIN) dan Majelis Agama Khonghucu Indonesia (MAKIN), yang semuanya berjumlah 8 orang narasumber. Pemilihan narasumber yang diwawancarai tersebut dipilih secara purposive dengan beberapa pertimbangan seperti: beragama Khonghucu, mengetahui problematika dan kebutuhan yang diinginkan.

$\begin{array}{ccr}\text { Data } & \text { dianalisis dengan } \\ \text { menggunakan teknik Miles dan }\end{array}$ Huberman, yaknireduksidata(pemilahan, pemusat perhatian), penyajian (display) data dan penarikan kesimpulan. Analisis diawali dengan proses mengatur urutan data, mengorganisasikannya ke dalam suatu pola, mengkategorikan serta membuat satuan uraian dasar. Data yang diperoleh pada tahap studi pendahuluan sampai akhir penelitian, dikumpulkan terlebih dahulu, lalu disusun sesuai urutan yang tepat berdasarkan kebutuhan penelitian. Semua yang dipaparkan responden dicatat selengkap-lengkapnya sambil melakukan analisis. Kegiatan berikutnya adalah mengklasifikasikan data berdasarkan masalah yang perlu dijawab. Dalam penelitian ini lokasi penelitian adalah Provinsi DKI Jakarta karena menjadi salah satu daerah yang terdapat umat Khonghucunya.

\section{HASIL DAN PEMBAHASAN}

\section{Gambaran Umum Kehidupab Agama di DKI Jakarta}

\section{Gambaran Geografis dan Demografis di Provinsi DKI Jakarta}

Provinsi DKI Jakarta merupakan Ibu Kota Negara yang menjadi barometer Indonesia dalam berbagai bidang. Batasbatas wilayah sebelah utara adalah Laut Jawa, sebelah selatan adalah Kota Depok, sebelah timur adalah Provinsi Jawa Barat, dan sebelah barat adalah Provinsi Banten. Sebagian besar wilayah merupakan daratan berdataran rendah dengan luas $662,33 \mathrm{~km} 2$. Secara administrasi, Provinsi DKI Jakarta terbagi menjadi 5 wilayah kota administrasi dan 1 kabupaten administrasi. Wilayah administrasi di bawahnya terbagi menjadi 44 kecamatan dan 267 kelurahan (BPS DKI Jakarta, 2016).

Jumlah penduduk DKI Jakarta tahun 2015 berdasarkan hasil Sensus Penduduk 2010 sebesar 10.177.924 jiwa dengan laju pertumbuhan penduduk per tahun sebesar 1,02 persen (BPS DKI Jakarta, 2016). Kepadatan penduduk DKI Jakarta tahun 2015 adalah 15.366,87 jiwa setiap $1 \mathrm{~km}^{2}$. Sebagai Ibu Kota Negara, Jakarta terdiri atas berbagai suku bangsa.

Umat beragama di DKI Jakarta terkenal dapat saling bekerjasama 
dalam memajukan wilayahnya. Kondisi kerukunan hidup beragama ini dipandang relatif kondusif di tengah beragamnya kehidupan keagamaaan yang diwakili oleh keragaman penganut agama.

Namun demikian sangat disayangkan belum ada data terbaru tentang jumlah penduduk DKI Jakarta berdasarkan agama. Data yang bisa dipergunakan sejauh ini berasal dari data lama hasil sensus tahun 2010. Pada data tersebut terdapat informasi bahwa agama mayoritas adalah Islam 8.200.796 $(85,36 \%)$, diikuti dengan Kristen 724.232 $(7,54 \%)$, Katholik $303.295(3,16)$, Hindu $20.364(0,21 \%)$, Buddha 317.527 (3,30\%), Khonghucu $2.410 \quad(0,06 \%)$, lain-lain sebanyak $2.410(0,03 \%)$ dari sebanyak 9.607.787 jiwa penduduk (BPS Pusat, 2010).

Sedikit berbeda dengan data di atas, data yang dirilis Dinas Kependudukan dan Pencatatan Sipil Provinsi DKI Jakarta tahun 2015 terkait penduduk yang beragama Khonghucu sebanyak 992 jiwa (Dinas Kependudukan dan Pencatatan Sipil, 2015).

Keragaman juga terlihat dari banyaknya tempat-tempat ibadah seperti 3.047 mesjid, 5.620 mushola, 1.098 gereja Kristen, 45 gereja Katolik, 27 pura, 292 vihara di mana di dalamnya terdapat Kelenteng (BPS DKI Jakarta. 2016). Keragaman agama di DKI Jakarta meniscayakan potensi persinggungan kepentingan di berbagai lapangan.

\section{Gambaran Umat Khonghucu di Provinsi DKI Jakarta}

Jumlah Kelenteng yang menjadi tempat ibadah umat Khonghucu bisa dikatakan masih sedikit. Jumlah tersebut bahkan hampir tidak ada bila yang menjadi ukuran adalah tempat ibadah yang dibangun dan dikelola secara swadaya oleh internal umat Khonghucu. Saat ini di seluruh wilayah DKI Jakarta hanya ada satu buah Kelenteng yang sesuai dan ada dalam pengelolaan MATAKIN DKI Jakarta, bertempat di TMII. Kekurangan jumlah tempat ibadah berupa Kelenteng ini kemudian disiasati dengan pendirian Lithang di beberapa tempat.

Jumlah keseluruhan Lithang dan Kelenteng (yang dikelola secara swadaya oleh kalangan internal umat Khonghucu) di DKI Jakarta saat ini sebanyak 5 buah. Penyebutan Lithang mendahului Kelenteng tidak ada tujuan lain kecuali untuk menunjukkan bahwa keberadaan tempat ibadah yang dominan dimiliki umat Khonghucu di DKI Jakarta adalah Lithang.

UmatKhonghucuDKIJakartasejauh ini tidak dapat diketahui jumlahnya. Selain karena tidak adanya data, juga disebabkan oleh jumlah umat yang beribadah di Kelenteng maupun Lithang tidak mewakili jumlah keseluruhan umat Khonghucu. Sebab lainnya disinyalir masih ada umat yang kesehariannya beribadah secara Khonghucu namun dalam pencatatan identitas KTP masih tercantum sebagai umat Buddha atau Kristen. Hal ini dapat dipahami sebagai imbas dari kebijakan pemerintah Orde Baru dengan diterbitkannya Instruksi Presiden Nomor 14 Tahun 1967, yang salah satunya adalah pelarangan ajaran agama Khonghucu sehingga umatnya dipaksa untuk bergabung ke dalam agama Buddha. 
Tabel 1. Perbedaan Lithang dan Kelenteng

\begin{tabular}{|c|l|c|c|}
\hline No & \multicolumn{1}{|c|}{ Atribut } & Lithang & Kelenteng \\
\hline 1 & Kepemilikan & Milik umum & Milik Khonghucu \\
\hline 2 & Fungsi & Tempat ibadah & $\begin{array}{c}\text { Tempat belajar agama } \\
\text { Khonghucu }\end{array}$ \\
\hline 3 & Jumlah Para Suci & Satu & Lengkap \\
\hline 4 & Ornamen & Lebih ke arah aula & Banyak altar \\
\hline 5 & Hubungan & Saling kenal & Tidak saling kenal \\
\hline 6 & $\begin{array}{l}\text { Kedekatan dengan pusat } \\
\text { keramaian }\end{array}$ & Tidak mesti dekat pasar & Dekat pasar \\
\hline 7 & Cara beribadah & Sendiri-sendiri & Bersama-sama \\
\hline 8 & Keberadaan senming & Tidak ada senming & Ada senming \\
\hline 9 & Jam ibadah & Dersama-sama & Tidak dibatasi \\
\hline 10 & Tata cara berdoa & Lebih kecil & Pribadi dan bersama-sama \\
\hline 11 & Besar bangunan & Bisa ada dan bisa tidak ada & Lebih besar \\
\hline 12 & Keberadaan Ciam Sie & Ada \\
\hline
\end{tabular}

Sumber :

Diolah dari hasil wawancara dengan Peter Lesmana, Ketua MAKIN Jakarta Barat, 12 Mei 2017

Untuk penganut Khonghucu di Kelenteng TMII, diperoleh informasi ada 100 orang penganut yang aktif ibadah setiap tanggal 1 dan 15 bulan Imlek. Jumlah anggota yang hadir saat ibadah tahunan cenderung meningkat terutama menjelang imlek hingga mencapai 200 orang. Dilihat dari sisi etnis, bahwa umat Khonghucu didominasi oleh etnis Tionghoa, hal ini disebabkan selain karena kesamaan asal agama, juga lekat dengan budaya leluhur yang tidak dapat ditinggalkan begitu saja.

Di DKI Jakarta, umat Khonghucu bernaung di bawah MATAKIN DKI Jakarta yang membawahi 4 MAKIN, yakni ; MAKIN Jakarta Pusat, Jakarta Timur, Jakarta Barat dan Jakarta Utara. Jumlah rumah ibadah khusus Khonghucu (Lithang) sesuai dengan jumlah MAKIN yang ada yakni 4 buah, walaupun disinyalir jumlah tersebut bisa melebihi 4 buah karena semasa pelaksanaan Instruksi Presiden Nomor 14 Tahun 1967 tentang Agama, Kepercayaan, Adat Istiadat Cina banyak rumah ibadah seperti Kelenteng yang diambil alih oleh umat Buddha.

\section{Ajaran dan Peribadatan}

Ajaran Pokok

Agama didefinisikan sebagai seperangkat aturan dan peraturan yang mengatur hubungan manusia dengan Tuhannya, mengatur hubungan manusia dengan manusia lainnya, dan mengatur hubungan manusia dengan lingkungannya. Agama berisikan ajaran mengenai kebenaran tertinggi dan mutlak tentang eksistensi manusia dan petunjuk-petunjuk untuk hidup selamat baik di dunia maupun di akhirat. Dengan demikian agama mengajarkan kepada manusia tentang aturan hidup manusia menurut petunjuk Tuhan Yang Maha Esa.

Agama Khonghucu hadir di sekitar abad keenam sebelum Masehi di tengahtengah kekacauan politik, maupun suasana keagamaan yang rawan di Cina. Agama Khonghucu telah meninggalkan kesan yang kuat dalam kehidupan dan kebudayaan China. Kong $\mathrm{Hu} \mathrm{Chu}$ dianggap oleh Cina sebagai Guru yang pertama bukan karena ketiadaan Guru sebelum beliau, tetapi karena beliau 
memperbaiki kehidupan masyarakat (Us-Samad, Ulfat Aziz, 1990 : 97). Masa Khonghucu ini berada di tahun 551 SM (Tanggok, M. Ikhsan, 2005 : 24) beliau ini dikenal dengan nama Nabi Kongzi (MATAKIN. 2016 : 2).

Agama Khonghucu adalah agama yang monotheis, yakni agama yang mempercayai dan meyakini adanya satu Tuhan atau percaya hanya pada satu Tuhan. Istilah Tuhan dalam agama Khonghucu dinamakan Thian untuk menunjuk kepada Tuhan Yang Maha Esa. Ajaran agama Khonghucu berisikan landasan dan sasarannya adalah jalan suci yang dibawakan ajaran agama, menegakkan firman Thian dan mengamalkannya hingga mencapai summun bonnum (kebahagiaan hidup). Dengan kata lain dapat dikatakan bahwa ajaran agama Khonghucu pada dasarnya mengikuti jalan suci Tuhan Yang Maha Esa dan menegakkan jalan suci manusia (MATAKIN. 2016 : 3). Agama ini disebut juga sebagai Ji Kauw dan Ru Jiao yang bermakna sebagai agama yang mengajarkan kelembutan atau agama bagi kaum terpelajar (Chandra, Adjie, $2012: 21)$.

Tiap umat Khonghucu wajib memahami, menghayati dan mengimani dasar keimanannya yang pokok, yang tersurat di dalam Bab Utama Ajaran Besar dan salam iman yang tersurat di dalam Kitab Shu Jing. Dalam Yijing dijelaskan bahwa Tuhan itu Maha Sempurna, dan Maha Pencipta (Yuan), Maha Menjalin, Maha Menembusi dan Maha Luhur (Heng), Maha Pemurah, Maha Pemberi Rahmat dan Maha Adil (Li) dan Maha Abadi Hukumnya (Zhen) (Chandra, Adjie, 2012 : 23). Dalam agama Khonghucu, dikenal juga konsep hubungan vertikal dengan Thian dan hubungan horizontal dengan sesama manusia. Dalam berbagai kesempatan, Nabi Kongzi menekankan pentingnya manusia memiliki ; tiga pusaka kehidupan dan tiga mutiara kebajikan (Chandra, Adjie, 2012 : 24).

\section{Ritual Puja Bakti}

Ibadah dalam agama Khonghucu sebagaimana dalam ajaran agama lainnya dapat berupa kebaktian/sembahyang baik di Lithang/Kelenteng maupun di rumah ditujukan kepada Thian (MATAKIN. 1984 : 35). Selain itu juga dengan melakukan kebaktian kepada Nabi, para Suci, leluhur dan kemasyarakatan (MATAKIN. 1984 : 35).

Dengan demikian, kebaktian dalam agama Khonghucu bisa bersifat mengucap rasa syukur, mengingat jasa para Nabi dan para Suci, juga menjadikan hidup senantiasa diwarnai oleh aneka manfaat bagi sesama. Tiap kebaktian atau sembahyang tersebut setidaknya mengikuti siklus tertentu. Ada yang harian, bulanan hingga tahunan.

Sarana ibadah umat Khonghucu terlihat dari fasilitas yang dimiliki oleh Lithang atau Kelenteng. Sarana ibadah tersebut dapat berupa meja sembahyang, persembahan, alat upacara, maupun upacara yang dilaksanakan. Banyaknya ummat Khonghucu yang beribadah di Lithang atau Kelenteng karena adanya fasilitas, prosesinya lengkap dan lebih hikmat. Berdasarkan Tabel 2, dapat disebutkan bahwa altar pada Lithang secara sederhana terbagi menjadi dua bagian utama, yaitu altar belakang dan altar depan. Masing-masing bagian altar tersebut memiliki fungsi tersendiri sesuai dengan makna yang dikandungnya dan diharapkan dapat dipelajari dan diteladani oleh umat Khonghucu. 
Tabel 2. Struktur Altar pada Lithang di DKI Jakarta

\begin{tabular}{|c|c|c|c|}
\hline No & Area & Komponen & Makna \\
\hline \multirow[t]{6}{*}{1} & \multirow{6}{*}{$\begin{array}{l}\text { Altar } \\
\text { belakang }\end{array}$} & Arca nabi & \\
\hline & & Kitab suci Shu si & \\
\hline & & Tempat bakar surat do'a & \\
\hline & & Tempat api dari kaca & \\
\hline & & Lilin sepasang & $\begin{array}{lll}\text { Simbol } & \text { keseimbangan } & \text { dan } \\
\text { keserasian } & & \end{array}$ \\
\hline & & Bunga sepasang & Lambang kesejahteraan \\
\hline \multirow[t]{7}{*}{2} & \multirow{7}{*}{$\begin{array}{l}\text { Altar } \\
\text { depan }\end{array}$} & Khiolo (tempat dupa) & Persembahan \\
\hline & & Lilin sepasang & $\begin{array}{lll}\text { Simbol keseimbangan } & \text { dan } \\
\text { keserasian } & & \\
\end{array}$ \\
\hline & & Swanlo (tempat membakar wewangian) & \\
\hline & & $\begin{array}{l}\text { Lak chu (alat untuk mengambil api dan } \\
\text { menyalakan lilin) }\end{array}$ & \\
\hline & & $\begin{array}{l}\text { Tok ui (spanduk bergambar kilin yaitu } \\
\text { sepasang naga), }\end{array}$ & $\begin{array}{l}\text { Nabi Khongzi sewaktu lahir } \\
\text { menampakkan diri }\end{array}$ \\
\hline & & $\begin{array}{l}\text { Bok Tok bertuliskan "setia kepada tuhan, } \\
\text { tepa salira kepada agama" }\end{array}$ & $\begin{array}{l}\text { Lambang bahwa Nabi Khongzi } \\
\text { membawa firman Thian }\end{array}$ \\
\hline & & $\begin{array}{l}\text { Kitab kumala bertuliskan "akan lahir } \\
\text { seorang raja tanpa mahkota" yang } \\
\text { disemburkan dari kilin ke depan ibu } \\
\text { Gan Thin Cay }\end{array}$ & $\begin{array}{l}\text { Lambang Nabi Khongzi dilahirkan } \\
\text { membawa misi dari Thian }\end{array}$ \\
\hline
\end{tabular}

Sumber :

Diolah dari hasil wawancara dengan Liliany Lontoh, Ketua MATAKIN DKI Jakarta, 15 Mei 2017

Esensi beribadah atau bersembahyang di Kelenteng, pada dasarnya melakukan kebaktian kepada para suci atau Shengmin. Ibadah atau

sembahyang ini mencerminkan tingkat ketaatan tinggi sekaligus sebagai perwujudan syukur kepada Tuhan Yang Maha Esa.

Tabel 3. Shengmin pada Kelenteng Khong Miao TMII

\begin{tabular}{|c|l|l|c|}
\hline No & \multicolumn{1}{|c|}{ Nama shengmin } & \multicolumn{1}{|c|}{ Atribut } & Eksistensi \\
\hline 1 & Kwan im nio nio & Welas asih & Spirit \\
\hline 2 & Tian Shang Sheng Mu & Penyelamat manusia & Spirit \\
\hline 3 & Fu De Zheng Sen & Mengatur semua hal di bumi & Spirit \\
\hline 4 & Xuan Tian Shang Di & Malaikat bintang utara & Spirit \\
\hline 5 & Guang Gong & Adil dan bersahabat & Nyata \\
\hline 6 & Guang Ze Zun Wang & Berbakti pada orang tua & Nyata \\
\hline
\end{tabular}

Sumber :

Diolah dari hasil wawancara dengan Rini Antika, Pengelola Kelenteng Khong Miao, 14 Mei 2017 
Seluruh rangkaian kebaktian tersebut harus mengacu pada kebaktian secara umum, yang meliputi ; persiapan, penaikan dupa, penaikan do'a, penghormatan, nyanyian pembuka, khotbah pertama, nyanyian pujian, khotbah kedua, nyanyian pujian, wartawarta, do'a penutup dan nyanyian penutup.

\section{Ajaran Etika/Moral}

Jalan suci Thian dapat ditempuh melalui delapan pengakuan keimanan, yaitu ; 1) Sing Sien Hong Thian, artinya: sepenuh iman percaya kepada Tuhan yang Maha Esa, 2) Sing Cun Khoat Tik, artinya : sepenuh iman menjunjung kebajikan, 3) Sing Liep Bing-Bing, artinya: Sepenuh iman menegakkan firman Gemilang, 4) Sing Ti Kwi Sien, artinya: sepenuh iman menyadari adanya nyawa dan roh, 5) Sing Yang Hau Su, artinya: sepenuh iman menempuh cita berbakti, 6) Sing Sun Bok Tok, artinya: sepenuh iman mengikuti genta rohani, 7) Sing Khiem Su Si, artinya: sepenuh iman memuliakan kitab Su Si, 8) Sing Hing Tai Too, artinya : sepenuh iman menempuh jalan suci (Bidang Bimas Khonghucu, 2012 : 47). Keimanan yang pokok bagi umat Khonghucu terkandung di dalam bab utama kitab Zhong Yong, bab utama kitab Da Xue dan salam seiman yang terkandung dalam kitab Shu Jing (Bidang Bimas Khonghucu, 2012 : 47).

\section{Kitab Suci}

Kitab suci agama Khonghucu sampai pada bentuknya yang sekarang mengalami perkembangan yang sangat panjang. Kitab suci yang tertua berasal dari Yao (2357-2255 SM) atau bahkan bisa dikatakan sejak Fu Xi (30 abad SM). Yang termuda ditulis cicit murid Kongzi, bernama Mengzi (wafat 289 $\mathrm{SM})$, yang menjabarkan dan meluruskan ajaran Kongzi, yang waktu itu banyak diselewengkan. Kitab suci yang berasal dari Nabi Purba sebelum Kongzi, ditambah Chunqiujing (Kitab atau Catatan Jaman Cun Ciu/ Musim Semi dan Musim Rontok) yang ditulis sendiri oleh Kongzi, kemudian dihimpun Kongzi dalam Kitab Wujing.

Beberapa saat sebelum wafat, Nabi Kongzi mempersembahkan Wujing dalam persembahyangan kepada Thian. Wujing Five Classics sebagai kitab suci yang lima (The five books of old testement) terdiri atas:

1. Shijing (Kitab Sanjak), yang berisi nyanyian religi, puji-pujian akan keagungan Tian dan nyanyian untuk upacara di istana,

2. Shujing (Kitab Dokumentasi), yang berisi sejarah suci agama Khonghucu,

3. Yijing, berisi tentang penjadian alam semesta, sehingga mereka yang menghayati Kitab ini akan mampu menyibak takbir kuasa Tian dengan segala aspeknya,

4. Lijing (Kitab Kesusilaan), yang berisi aturan dan pokok-pokok kesusilaan dan peribadahan, serta

5. Chunqiujing. Pokok-pokok ajaran dan sabda-sabda Nabi Kongzi sendiri, kemudian dihimpun oleh muridmuridnya dalam sebuah Kitab Suci yang disebut Si Shu (Kitab Suci Yang Empat) (Bidang Bimas Khonghucu, 2012 : 42-44).

Si Shu yang merupakan kitab suci yang empat (The four books of old testement) terdiri atas :

1. Daxue (Ajaran Agung/Besar) yang berisi bimbingan dan ajaran pembinaan diri, keluarga, masyarakat, negara dan dunia. Daxue ditulis oleh Zengzi atau Zengshen, murid Kongzi dari angkatan muda, 
2. Zhongyong (Tengah Sempurna) yang berisi ajaran keimanan agama Khonghucu. Zhongyong ditulis oleh Zisi atau Kongji, cucu Kongzi,

3. Lunyu (Sabda Suci) yang berisi percakapan Kongzi dengan muridmuridnya. Kitab ini dibukukan oleh beberapa murid utama Kongzi, yang waktu itu berjumlah 3.000 murid, dimana 72 orang diantaranya tergolong murid utama, dan

4. Kitab Mengzi yang ditulis Mengzi. Kitab ini terdiri atas tujuh jilid yang merupakan kumpulan tulisan yang mencatat ajaran dan percakapan Mengzi dalam menghadapi kemelut di zamannya (Bidang Bimas Khonghucu, 2012 : 45-46).

\section{Hari Suci}

Hari yang dianggap suci oleh penganut agama Khonghucu yang banyak orang kenal di antarannya ; Tahun baru Imlek, Cap Go Meh, dan Cheng Beng. Meskipun demikian, masih banyak hari lainnya yang dianggap suci oleh umat Khonghucu. Hari suci agama Khonghucu dapat ditemukan setidaknya dua kali dalam satu bulan. Di antara hari suci tersebut, ada yang digunakan untuk sembahyang dan ada pula yang merayakan suatu peringatan tertentu.

\section{Hubungan Sosial Umat Khonghucu}

\section{Relasi Sosial Inter dan Antar Agama}

Pengurus MATAKIN Provinsi DKI Jakarta dan MAKIN Kota se DKI Jakarta sebagaimana organisasi pada umumnya terdiri atas berbagai jabatan seperti unsur ketua, wakil ketua, sekretaris, bendahara dan berbagai unsur ketua bidang. Semua jabatan tersebut diadakan dalam rangka memudahkan pembagian kerja di antara pengurus bersangkutan. Hubungan antar anggota pengurus majelis diluaran penyelenggaraan musyawarah bersifat informal. Artinya, sesama pengurus dapat melakukan hubungan biasa.

Relasi sosial MATAKIN Provinsi DKI Jakarta dengan majelis agama lainnya berjalan cukup baik terutama dengan unsur majelis. Hubungan baik ini dibuktikan dengan diakuinya pengurus MATAKIN untuk menjadi salah satu anggota FKUB Provinsi DKI Jakarta. Belum lagi hubungan di luar FKUB, seperti dalam organisasi lintas sektoral semisal Forum Harmoni Umat Bangsa atau Forum Cinta Tanah Air. Kerjasama MATAKIN Provinsi DKI Jakarta juga dilakukan dengan Rumah Sakit dalam hal layanan kedukaan, kerjasama dengan PEMDA DKI Jakarta terkait Keluarga Berencana dan lain sebagainya.

Menyangkut pergaulan di antara masyarakat luas (antar penganut agama), penganut agama Khonghucu relatif cukup terbuka. Namun demikian, umat Khonghucu yang kebanyakan beretnis Tionghoa nampaknya kurang dapat bergaul dengan non Tionghoa, kalau ada orang asing yang belum dikenal masuk ke sebuah gang contohnya, maka mereka cenderung tertutup, kecuali bila pergaulannya berbentuk kerjasama usaha.

Secara eksternal, saling menghormati antar pemeluk agama terjadi terutama dengan sesama penduduk Tionghoa saat malam tahun baru imlek. Dalam beberapa tahun belakangan ini bahkan ada suatu fenomena baru yang menarik untuk dicermati yaitu ikut dirayakannya imlek di Gereja ataupun di Vihara. Sementara itu, hubungan dengan kalangan Muslim sejauh ini masih sangat kondusif di tengah adanya kekhawatiran akan efek 
tindakan Ahok dengan kasus penodaan agamanya dapat mempengaruhi relasi sosial di DKI Jakarta.

Relasi sosialantaraumatKhonghucu yang diwakili oleh MAKIN Kota dan MATAKIN Provinsi dengan pemerintah juga berjalan dengan baik. Hal tersebut dibuktikan dengan kehadiran perwakilan pemerintah baik dari pemerintah daerah maupun Kemenag (baik kabupaten/kota maupun dari kantor wilayah provinsi) dalam berbagai acara seperti pelantikan pengurus MAKIN/MATAKIN ataupun kegiatan lainnya.

\section{Konflik yang Pernah Terjadi}

Sejauh ini belum ada konflik yang memasuki tahapan agresi (yaitu kekerasan yang berhadapan dengan kekerasan) antar agama Khonghucu dengan berbagai agama lainnya. Meskipun demikian, tercatat beberapa gesekan yang terjadi di antaranya ; a) terkait dengan masalah pengambil alihan Kelenteng sebagai tempat ibadah umat Buddha, b) konflik dalam bidang pendidikan.

Terkait dengan konflik dalam bidang pendidikan ini pernah ada kasus di suatu sekolah di mana kepala sekolah beragama lain mengajak siswa beragama Khonghucu untuk belajar agama lain. Meski di sana memang tidak ada guru agama Khonghucu, namun seharusnya pengajaran agama tersebut diserahkan kepada Majelis agama Khonghucu untuk dicarikan gurunya. Upaya konversi agama Khonghucu ke Kristen / Katolik / Buddha lebih banyak terjadi lewat media pendidikan. Hal ini terjadi karena di sekolah tersebut hampir tidak ada guru agama Khonghucu, sehingga siswa ikut belajar mempelajari ajaran agama lain.

\section{Bentuk Layanan Keagamaan}

Layanan Keagamaan yang Sudah dan Belum Diberikan oleh Pemerintah

\section{Layanan Pendidikan}

Dalam hal pendidikan, umat Khonghucu masih memiliki berbagai keluhan meskipun pemerintah telah mengeluarkan PPNo. 5 tahun 2007 tentang Pendidikan Agama dan Pendidikan Keagamaan bagi umat Khonghucu dan memasukan pendidikan agama Khonghucu dalam kurikulum nasional. Selain itu juga telah terbit Peraturan Menteri Pendidikan nasional Bo. 47 tahun 2008 tentang standarisasi Isi mata pelajaran agama Khonghucu. Didukung pula dengan terbitnya PP Menteri Pendidikan Nasional Nomor 48 Tahun 2008 tentang Standar Kompetensi Lulusan Mata Pelajaran agama Khonghucu, Pada pasal 45 ayat 1 menyatakan bahwa pendidikan Khonghucu diselenggarakan oleh masyarakat pada jalur pendidikan formal, non formal, dan informal.

Pada kenyataannya, masih banyak sekolah yang belum memberikan pendidikan keagamaan yang seharusnya kepada pemeluknya, terutama penganut agama Khonghucu. Sebagai contoh, seharusnya bila sekolah tidak menyediakan guru sesuai dengan agama penganut agama Khonghucu, maka sekolah dapat menyerahkan pendidikan tersebut kepada tempat ibadah agama bersangkutan, dalam hal ini kepada Kelenteng atau Lithang. Namun ternyata semua hal tersebut tidak terjadi. Alihalih menyerahkan kepada pihak lain yang berkompeten dalam memberikan pendidikan keagamaan, malahan pada beberapa sekolah swasta telah diberikan pengajaran kepada siswa dalam mata pelajaran agama di luar keyakinan siswa yang beragama Khonghucu ini. 
Dari sisi guru agama Khonghucu yang volunteer di sekolah tidak diberikan UMP Provinsi. Belum lagi pengakuan sekolah yang belum maksimal dalam menerima keberadaan guru agama Khonghucu yang seakan tidak memperhatikannya. Hal ini terjadi karena belum ada juklak dan juknisnya oleh Kemenag. Secara administrasipun ketika kolom agama dalam form pendaftaran pilihannya belum ada pilihan agama Khonghucunya, melainkan berupa titiktitik. Hal tersebut juga terjadi dalam buku induk pendidikan di sekolah, daftar dapodik, raport, kelulusan dan ijazah.

Pada beberapa sekolah yang sudah menerima agama Khonghucu sebagai salah satu mata pelajaran yang diajarkan pun masih kerap ditemukan masalah. Seperti dalam kasus menilai ujian praktek agama yang tidak diserahkan kepada guru agama Khonghucu tetapi kepada guru lain agama yang tersedia di sekolah tersebut. Dari seluruh sekolah yang ada di Jakarta, baru 15 sekolah yang menyelenggarakan pendidikan agama Khonghucu yang rata-rata berada di sekolah swasta. Selain jenis layanan pendidikan reguler dalam hal ini adalah kelas klasikal.

\section{Layanan Kependudukan}

Secara umum, ada perasaan dari sebagian umat bahwa umat Khonghucu dihambat. Hal ini menjadi penyebab keluarga yang sudah pindah ke agama lain juga tidak mau pindah lagi ke agama Khonghucu karena takut ada perkara seperti masa lalu. Maka dari itu, masalah layanan pemerintah terkadang selalu dikaitkan dengan perasaan ini. Terkait layanan kependudukan ini meliputi pengurusan ; KTP, Akta Lahir, Akta nikah, dan pemakaman. Dalam hal ini, permasalahan KTP tidak terletak di tangan pemerintah tetapi lebih kepada pihak umat yang enggan untuk berganti status agama di KTP. Selain karena anggapan masalah KTP hanya berupa catatan saja, yang penting sembahyang tetap ke Kelenteng.

Berdasarkan wawancara yang dilakukan dengan penganut Khonghucu, sampai sekarang ini ternyata masih ada masalah tentang akta lahir di mana status anak berasal dari ibu bukannya ayah, karena orang tua dahulu tidak menikah di catatan sipil. Dahulu memang akibat pernikahan yang tidak dicatatkan di pencatatan sipil menjadikan status anak dalam sebuah keluarga Khonghucu hanya dapat dinisbatkan kepada ibunya dalam Kartu Keluarga. Seiring dengan waktu meskipun sekarang keberadaan agama Khonghucu sudah diakui berikut hak-hak sipilnya namun masalah perubahan status tersebut masih sangat sulit dilakukan.

Dalam melaksanakan prosesi pernikahan, umat Khonghucu dapat melaksanakannya di tempat ibadah, baik di Lithang maupun di Kelenteng. Prosesi tersebut dilanjutkan tentunya dengan mencatatkan pernikahan ke pencatatan sipil. Pada beberapa tahun terakhir, pernikahan ini sudah mendapatkan banyak kemudahan dari instansi terkait. Ketika umatada yang mendapatikematian pada keluarga atau kerabat, pemakaman dilakukan di tempat terdekat. Biasanya di tempat pemakaman umum. Untuk proses penguburannya secara izin sudah tidak sesulit dahulu.

\section{Layanan Keagamaan yang Dibutuhkan}

Selain layanan kependudukan yang diperlukan umat Khonghucu, ternyata ada layanan lain yang sangat diperlukan, yaitu layanan keagamaan. Hasil wawancara kepada beberapa narasumber menghasilkan beberapa temuan penting di antaranya : 


\section{Bidang Status Hukum}

Pemulihan harus dilakukan oleh Kementerian terkait (Sekneg dan Mendagri) terkait aturan perundangundangan eksistensi agama Khonghucu. Karena Inpres yang mencabut pelarangan simbol-simbolKhonghucuuntuk tampildi publik belum dieksekusi secara sempurna. Misalnya ; Hari keagamaan Imlek masih dianggap "tradisi" bukannya upacara keagamaan, sehingga bisa dilaksanakan di Gereja atau Vihara. Padahal Imlek sebagai upacara keagamaan eksklusif milik umat Khonghucu.

\section{Bidang Keagamaan}

Pendirian rumah ibadah yang mandiri (sebagai padanan dari penggunaan rumah ibadah bersama dengan penganut agama lain), karena selama ini Kelenteng jadi rumah ibadah yang dibagi dengan 2 agama lainnya yaitu Buddha dan Tao (Tridharma). Selama ini tempat ibadah yang sudah turun temurun dipaksa di masa lalu menjadi Vihara. Di sini seolah-olah ada penstigmaan terhadap tempat ibadah agar konversi jadi Vihara. Sebagai tambahan, seolah-olah ada kesengajaan pembatasan hak beribadah dengan cara "mereka" menyelenggarakan kegiatan Tridharma pada waktu yang menjadi jatah umat Khonghucu melaksanakan ibadah. Masalah yang mendera disekitaran isu Tridharma tentunya memerlukan penyelesaian secepatnya (yaitu harus diberi ketentuan jam dan tempatnya).

Penyelesaian

peruntukkan

Kelenteng yang saat ini masih digunakan oleh Tridharma. Hal tersebut didasarkan pada fakta historis dan peninggalan ornamen fisik adalah tipikal Kelenteng (berasal dari ajaran Khonghucu yang terdapat pada kitab suci Shi Shu). Dengan demikian diharapkan Kemenag dapat memediasi Majelis Agama Khonghucu dengan Majelis Agama Buddha terkait masalah pengelolaan Kelenteng yang hendaknya difungsikan ke semula, termasuk dalam hal ornamen disesuaikan dengan Kitab Suci Shu Shi. Ajaran dikembalikan ke fitrahnya karena dahulu dipersepsikan terjadi sinkretisme agama, padahal yang sebenarnya tidak demikian.

Selain pengembalian ajaran Khonghucu yang dikembalikan pada asalnya, alat-alat pemujaan yang ada di Kelentengjuga menurut umat Khonghucu hendaklah dikembalikan pada fungsi semula. Indikasinya lihat di kitab suci, jangan sampai nama Shengmin dibajak oleh agama lain padahal tidak ada dalam kitab sucinya.

\section{Bidang Layanan Hak Sipil}

Masih banyaknya ketakutan akan dipersulit ketika umat Khonghucu mengurus keadministrasian. Untuk mengatasinya diperlukan sosialisasi tentang pengembalian hak sipil umat Khonghucu pada aparatur birokrasi sampai di tingkat bawah yang kebanyakan belum mengetahui dan seakan mempersulit layanan.

\section{Bidang Pembinaan Umat}

Rekrutmen penyuluh agama yang sangat penting bagi layanan terhadap umat terutama dalam hal layanan duka dan rohaniawan agama. Sedikitnya jumlah penyuluh agama Khonghucu selama ini dapat mengakibatkan kurang terlayaninya layanan keagamaan umat.

\section{Bidang Pendidikan}

Buku ajar pendidikan agama Khonghucu di sekolah internasional sangat dibutuhkan. Juga selama ini belum ada guru Agama Khonghucu yang diangkat sebagai PNS.

Jurnal Multikultural \& Multireligius Vol. 17 No.1 
9. 'Bidang Keorganisasian

Penanganan masalah umat Khonghucu hendaklah dilakukan oleh wakil umat Khonghucu, karena ia pastinya memahami masalah umat Khonghucu dan akan memperjuangkan pengembalian pengelolaan Kelenteng ke umat Khonghucu. Dualisme organisasi yaitu keberadaan MATAKIN dengan PARAKIN di mana pemerintah harus turun tangan menangani ini.

\section{Temuan Potensi Konflik serta Penyelesaiannya}

Keberadaan umat Khonghucu di DKI Jakarta ditunjukkan oleh tumbuh dan berkembangnya agama ini di daerah penelitian. Perkembangan agama Khonghucu di DKI Jakarta terjadi sudah sejak lama, yaitu tahun 1729, dibuktikan dengan diketemukannya Shu Yuan, semacam lembaga pendidikan agama berasrama yang memberikan pendidikan tentang agama Khonghucu ( $\mathrm{Ru}$ Jiao) bernama Ming Cheng Shu Yuan, yang bermakna "Taman kitab pendidikan menggemilangkan iman".

Beranjak ke zaman kemerdekaan berdirilah perkumpulan Khong Kauw Hwee di Jakarta yang menjadi cikal bakal MAKIN dan MATAKIN di berbagai daerah. Semangat kebersamaan semakin terlihat dengan perkembangan kalangan Tionghoa beserta dengan agama Khonghucunya. Namun tidak berselang lama, selepas tahun 1965 sejak dimulainya Orde Baru, hal-hal yang berkaitan dengan kalangan Tionghoa beserta dengan agama Khonghucu mendapatkan tekanan dari pemerintah saat itu. Seiring waktu, rezim Orde Baru pun surut dan mulailah dibuka era Orde Reformasi yang mengembalikan kondisi kalangan Tionghoa beserta dengan agama Khonghucu ke posisi semula.
Di sisi lain, pasang surut dinamika perkembangan agama tidak terkecuali dialami juga oleh umat Khonghucu. Pada masa perkembangan inilah memungkinkan terjadinya interaksi dengan berbagai agama dan aliran dalam bidang kehidupan sehari-hari. Membuka kemungkinan akan relasi positif maupun negatif dengan berbagai umat dan masyarakat.

Beberapa konflik yang rawan muncul, yaitu ; efek dari konversi agama, konflik dalam menggunakan Kelenteng, kegiatan misionari (agama non Khonghucu) yang terselubung dan masalah dalam pengajaran terhadap siswa beragama Khonghucu di sekolah yang tidak ada pengajar beragama Khonghucu. Adanya konflik dalam hal pengajaran, konflik terkait konversi agama maupun konflik penggunaan Kelenteng selama ini belum terselesaikan dengan baik sehingga rawan terjadinya tingkat eskalasi yang lebih tinggi di masa yang akan datang.

\section{Kebutuhan Layanan Keagamaan yang Relevan dengan Kekinian}

Di antara layanan pendidikan dan layanan kependudukan yang diberikan pemerintah, layanan pendidikan inilah yang paling banyak ditemukan permasalahan. Namun demikian terhadap kondisi ini tidak dapat berdiri sendiri dan selesai hanya dengan menyelesaikan satu aspek saja, melainkan harus semua aspek terselesaikan sehingga dapat saling bersinergi. Aspek pendidikan yang paling banyak mencatatkan permasalahan di antaranya ;

1. Kekurangan SDM guru yang dapat melayani kebutuhan pendidikan agama Khonghucu bagi siswa dari umat Khonghucu,

2. Kekurangan juklak dan juknis yang akan dapat memberikan pemahaman 
akan akses pendidikan yang seharusnya dapat diterima umat Khonghucu,

3. Kekurangan bahan ajar terutama bagi sekolah-sekolah internasional yang ada di DKI Jakarta,

4. Pemahaman yang kurang dari stakeholders pendidikan terhadap hak mendapatkan pendidikan terhadap umat Khonghucu.

Sementara itu, layanan yang dibutuhkan umat Khonghucu yang paling utama dapat disebutkan sebagaimana berikut ;

Bidang status hukum merupakan bidang yang paling krusial dan vital untuk dapat menyelesaikan permasalahan umat Khonghucu. Hal ini dapat dipahami karena hulu solusi adalah mengenai penyelesaian status hukum terlebih dahulu sehingga bidang lainnya dapat terurai dengan terukur dan teratur. Tingkat perkembangan agama Khonghucu sejak dipulihkan kembali hingga hari ini sebenarnya sudah hampir dua dasawarsa. Meskipun demikian, dalam persepsi umat Khonghucu nampaknya perkembangan agamanya seolah berjalan di tempat. Sebenarnya tidak cukup setelah status hukum dipulihkan sepenuhnya, tetapi juga aturan pelaksanannya juga perlu dipahami sampai ke tingkat umat.

Bidang keagamaan menjadi kebutuhan ke dua bagi umat Khonghucu. Hal ini disebabkan sengkarut masalah pengembalian rumah ibadah Kelenteng ke pengelolaan umat Khonghucu belum menemukan titik temu. Sengkarut masalah yang ditemukan di antaranya ; pembatasan hak beribadah dan pengembalian ajaran dan simbol keagamaan. Solusi yang diharapkan dapat menyelesaikan permasalahan tempat ibadah adalah dengan mendirikan tempat ibadah baru yang dibantu oleh pemerintah. Beberapa pertimbangan yang harus diperhatikan adalah: a) pendirian tempat ibadah agama lain pernah dibantu oleh pemerintah, b) kerugian immaterial umat Khonghucu selama ini dengan adanya aturan pembatasan sejak Orde Baru dapat dipulihkan dengan pengembalian hak sipil ke titik semula.

\section{SIMPULAN}

Berdasarkan paparan sebagaimana di atas dapat disebutkan beberapa kesimpulan sebagai berikut :

1. Di antara layanan pendidikan dan layanan kependudukan yang diberikan pemerintah, layanan pendidikan paling banyak ditemukan masalah.

2. Layanan yang dibutuhkan umat Khonghucu dapat disebutkan sebagaimana berikut; a) bidang status hukum, berupa pemulihan status hukum sampai kepada sosialisasi aturan pelaksanaan, b) bidang keagamaan, mulai dari pengembalian rumah ibadah Kelenteng ke pengelolaan umat Khonghucu sampai kepada pengembalian ajaran dan simbol keagamaan, c) bidang layanan hak sipil, d) bidang pembinaan umat, e) bidang pendidikan, f) bidang keorganisasian.

3. Penelitian ini tidak menemukan adanya konflik atau gesekan yang bersifat fisik. Namun tercatat konflik terselubung yang terjadi yaitu ; a) gesekan mengenai fungsi rumah ibadah Kelenteng, b) konflik dalam bidang pendidikan dan c) konflik akibat konversi agama terselubung. Relasi sosial ummat Khonghucu dengan masyarakat masih terbatas pada bidang-bidang tertentu. Sedangkan relasi dengan pemerintah menunjukkan hubungan yang erat. 


\section{Rekomendasi}

Penelitian ini sudah berupaya menjawab pertanyaan penelitian. Maka dari itu saran peneliti adalah :

1. Hasil penelitian ini secara umum kiranya dapat digunakan oleh Kementerian Agama RI, khususnya Kepala Pusat Bimbingan dan Pendidikan Khonghucu, sebagai bahan dalam menyusun kebijakan yang terkait dengan pembinaan keorganisasian dan layanan keagamaan umat Khonghucu.

2. Menyangkut hubungan antar agama khususnya terkait misionaris terselubung dalam pendidikan, perlu dilakukan pengawasan dan pembinaan melalui perangkat penyelenggara bimbingan masyarakat Khonghucu.

\section{UCAPAN TERIMA KASIH}

Di akhir tulisan ini, penulis sangat berterima kasih kepada Kepala Puslitbang Bimas Agama dan Layanan Keagamaan serta Kepala Badan Litbang dan Diklat Kementerian Agama RI yang telah memberikan kesempatan kepada penulis untuk melakukan penelitian tentang isu yang diangkat dalam tulisan ini, juga beberapa pihak dan informan yang terlibat dalam penggalian data dan informasi di dalamnya. Tidak ketinggalan, terima kasih juga penulis tujukan kepada Mitra Bestari dan Pengelola Jurnal Harmoni yang telah memberikan catatan dan saran untuk perbaikan tulisan ini, hingga bisa diterbitkan pada Jurnal Harmoni edisi kali ini.

\section{DAFTAR ACUAN}

Abidin, Zaenal., dan Safe'i, Agus Ahmad. Sosiophologi : Sosiologi Islam Berbasis Hikmah. Bandung: Pustaka Setia, 2002.

Bardis, Panos D “Social Interaction and Social Process". Social Science, No. 3, Vol. 54, Summer 1979.

Bidang Bimas Khonghucu. Kitab Pengantar Membaca Shi Su (Kitab Yang Empat) Kitab Suci Agama Khonghucu. Jakarta: PKUB, 2012.

BPS DKI Jakarta. Jakarta dalam Angka 2016. Jakarta: BPS DKI Jakarta, 2016.

BPS Pusat. Kewarganegaraan, Suku Bangsa, Agama, Dan Bahasa Sehari-Hari Penduduk Indonesia : Hasil Sensus Penduduk 2010. Jakarta: BPS, 2010.

Chandra, Adjie. Sekilas Riwayat Haksu Tjhie Tjay Ing. Jakarta: MATAKIN, 2012.

Dinas Kependudukan dan Pencatatan Sipil. 2015. http:// Data.Jakarta.go.id-/dataset/ jumlah-penduduk-provinsi-dki-jakarta-tahun-2015-berdasarkan-agama/ reseource/43d4e4ea-4ff0-4c41-a311-93b3066021a5 [diakses tanggal 30 Mei 2017]

Doyal L dan Gough I. A Theory of Human Need. London : MacMillan Education, Ltd, 1991.

Haryanto, Joko Tri. "Pembinaan Keagamaan Rohaniawan Khonghucu di Tuban Jawa Timur". Jurnal Analisa, No. 1, Volume XVII, Januari - Juni 2010

Ing, Tjhie Tjay. 50 th Sebagai Xueshi Xs. Tjhie Tjay Ing. Solo: MATAKIN PNR, 2013.

Kahmad, Dadang. Sosiologi Agama. Bandung: PT. Remaja Rosdakarya, 2009. 
MATAKIN. Tata Agama dan Tata Laksana Upacara Agama Khonghucu. Solo: MATAKIN, 1984.

MATAKIN. Seri Genta Suci Konfuciani No. 42/2016 Edisi Sincia 2567, Jakarta: MATAKIN, 2016.

Miller KA. 2005. "Human Motivation And Psychological Well-Being in A Sample of Clinical and Non-Clinical Adults." Thesis The Graduate School, Ball State University, Indiana, 2005.

‘Odea, Thomas F. Sosiologi Agama. terj. Yasogama. Jakarta: Rajawali Pers, 1990.

Scharf, Betty R. Sosiologi Agama. Jakarta: Kencana. 2004, 2004.

Soekanto, Soejono. Sosiologi Suatu Pengantar. Jakarta: Raja Grafindo Persada, 2009.

Sulaiman. “Agama Khonghucu: Sejarah, Ajaran dan Keorganisasiannya di Pontianak, Kalimantan Barat". Jurnal Analisa No. 1, Volume XVI, Januari - Juni 2009

Tanggok, M. Ikhsan. Mengenal lebih dekat Agama Khonghucu di Indonesia. Jakarta: Pelita Kebajikan, 2005.

Turner, Bryan S. Agama dan Teori Sosial. terj. Inyiak Ridwan Muzir. Yogyakarta: IRCiSod, 2006.

Turner, Jonathan H. A Theory of Social Interaction. California: Stanford University Press, 1988.

Us-Samad, Ulfat Aziz. The Great Religion of the World. Peshawar: AAIL, 1990. 